\title{
THE EFFECT OF CAPITAL ADEQUACY RATIO (CAR) AND LOAN TO DEPOSIT RATIO (LDR) ON NON PERFORMING LOAN (NPL) (CASE STUDY ON CONVENTIONAL COMMERCIAL BANKS IN INDONESIA ON 2016-2020)
}

\author{
Fajar Afriyanto ${ }^{1}$, Hilda Purnamawati ${ }^{2}$, Iyan Sukiman ${ }^{3}$ \\ $1,2,3$ Universitas Sangga Buana \\ ${ }^{1}$ korespondensi : kakangkarina@gmail.com
}

\begin{abstract}
This study aims to determine the influence of the Capital Adequacy Ratio (CAR) and Loan Deposit Ratio (LDR), both partially and simultaneously, on Non Performing Loans (NPL) in Conventional Commercial Banks in Indonesia for the period 2016-2020. This research is associative research with a quantitative approach. The data used in this study is secondary data, data analysis techniques using a data regression panel. Testing panel data include CEM, FEM and REM, Chow Test, Hausman Test, Lagrange Multiplier Test. Classic assumption tests include The Test of Normality, Heteroskedastisitas, Multicollinearity and Autocorrelation. Data analysis using correlation and determination coefficient analysis, Simultaneous and Partial Hypothesis Test. The population in this study was 99 Conventional Commercial Banks in Indonesia and a sample of 25 Conventional Commercial Banks in Indonesia with purposive sampling techniques. Based on the results of simultaneous hypothesis testing where CAR and LDR jointly have a significant effect on NPL Conventional Commercial Banks in Indonesia, the results off count $6.89>3.42 \mathrm{f}$ table with a significant rate of 0.001457 lower than the $\alpha 0.05$. While the partial hypothesis testing where CAR affects NPL Conventional Commercial Banks in Indonesia seen the results of $t$ count $-3,507<2,068 \mathrm{t}$ table with a signifies value of CAR of 0.0006 is smaller than $\alpha 0.05$. LDR has no effect on NPL of Conventional Commercial Banks with the calculation result of $-1,116<2,068 \mathrm{t}$ table with a significant LDR value of 0.2665 greater than $\alpha 0.05$.
\end{abstract}

Keywords : Non Performing Loan (NPL), Capital Adequacy Rati (CAR), Loan to deposit Ratio (LDR)

\section{INTRODUCTION}

In driving the economy of a country, banking is essential in understanding the high-level economy. Moreover, as an organization engaged in finance, banking involves a significant situation in financial events.

All sectors related to various financial activities always require the bank service. This is because banks are financial institutions that affect the economy, both micro and macro.

Most banks in Indonesia depend on layaway as a basic income to support their work. However, not all loans disbursed are safe, some of which carry a huge risk and can endanger the bank's health.
Because if there are a lot of bad advances, it will hamper the bank. That is the reason the Regular Business Bank was chosen as the object of examination. Ordinary Business Banks in maintaining their business do not involve customers as far as liability for the dangers. Regular banks are fully running premium frameworks. For clients who have shared their assets, the bank must ensure the arrival of the head and premium.

The funds are then channeled back to the community in the form of credit. The interest difference between the interest on the savings and the interest on the loan is the bank's profit. In this difference lies the most significant risk that the bank may experience because the bank must continue to pay back the customer's 
principal and interest following the agreed contract, but the customer does not share the risk of losses that may occur due to credit that may be problematic, in contrast to Islamic banks with the principle of profit-sharing where all forms of losses and profits are shared by the bank and the customer following the agreed contract. Although the average
NPL ratio (Non-Performing Loan) in conventional commercial banks in Indonesia from 2016 to 2020 does not exceed 5\%, as shown in Figure I.1, the value is relatively fluctuating. It shows that NPLs (NonPerforming Loans) are very vulnerable to unexpected changes.

Table 1. Average CAR, LDR NPL 99 Conventional Commercial Banks in Indonesia 20162020 Period (in \%)

\begin{tabular}{cccc}
\hline Year & CAR & LDR & NPL \\
\hline $\mathbf{2 0 1 6}$ & 22.93 & 90.70 & 2.86 \\
$\mathbf{2 0 1 7}$ & 23,18 & 90,04 & 2,50 \\
$\mathbf{2 0 1 8}$ & 22,97 & 94,78 & 2,33 \\
$\mathbf{2 0 1 9}$ & 21.42 & 94,00 & 2,47 \\
$\mathbf{2 0 2 0}$ & 22,67 & 90.55 & 2,74 \\
\hline \multicolumn{4}{l}{ Source : Bank annual report in $2016-2020$ (processed) }
\end{tabular}

Based on BI SE No.15/41DKMP dated October 1, 2013, the lower limit for capital rating determination is $8 \%$, and the average CAR of 99 Conventional Commercial Banks in Indonesia is declared good because it is above the specified standard. In determining the liquidity rating, the lower limit for LDR determined by $\mathrm{BI}$ is $75 \%$, and the upper limit is $100 \%$. Therefore, the average LDR of 99 Conventional Commercial Banks in Indonesia is at the standard determined by BI, so the ratio is declared good. In the NPL ratio, it can be seen that a bank is said to be healthy if it has an NPL value of less than $5 \%$, and if a bank has an NPL exceeding 5\%, then the bank is categorized as unhealthy. Therefore, 99 conventional commercial banks in Indonesia are good because they are below 5\%.

In table 1 above, it can be seen the inconsistency of financial ratio data such as
LDR and CAR. For example, the average value of the LDR ratio at conventional general banks in Indonesia from 2017 to 2018 increased from $90.04 \%$ to $94,78 \%$. In contrast, in previous years, it continued to decline. In addition, inconsistency showed by the average value of the CAR ratio at conventional commercial banks in Indonesia, which increased in 2018 (22,97\%) to 2019 $(23,42 \%)$ but continued to decline in the following year 2020 (21,67\%).

Based on the correct information in table 1.2 above, it is likely that there are holes that are not following the existing hypothesis. The price of the Capital Adequacy Ratio from 2019 to 2020 has increased from $21.42 \%$ to $22.67 \%$. However, the NPL has also increased from $2.47 \%$ to $2.74 \%$, contrary to the hypothesis that if the Capital Adequacy Ratio increases, NPL has decreased. According to 
the central bank, in terms of resilience, large capital is excellent. However, on the other hand, banks have not been able to utilize their capital optimally. (Source: Kontan.co.id). OJK deputy Commissioner for Banking Supervision II Slamet Edy Purnomo said the increase in non-performing loans was happened due to the high NPL in the processing sector. This occurred because of non-performing loans from the Duniatex group, which impacts this sector from upstream to downstream (cnbcindonesia.com). In the LDR ratio which according to theory, if the LDR increases, the NPL also increases. It turns out that there is a theoretical inconsistency where the LDR at conventional commercial banks in Indonesia from 2017 to 2018 has increased from $90.04 \%$ to $94.78 \%$. However, the increase in LDR is followed by a decrease in NPL from $2.50 \%$ in 2017 to $2.33 \%$ in 2018. According to the President Director of PT Bank, Maypada Internasional Tbk Hariyono Tjahjarijadi explained that the banking LDR condition is still high because the demand for credit is still not too much in early 2018 . This condition is because small and medium enterprises have not moved much. Large debtors prefer to issue debt securities or bonds. (Kontan.co.id). According to OJK, 2018 has fostered sufficient reserves so that the net NPL has decreased (Kontan.co.id).

\section{LITERATURE REVIEW}

NPL (Non Performing Loan)

The ratio in measuring asset quality is the NPL (Non-Performing Loan) ratio which shows the ability of bank management to manage nonperforming loans. The increase in the value of the NPL (Non-Performing Loan) indicates the worse the credit quality of a bank. [1] Determining the level of the sound quality of healthy productive assets states that the higher the NPL (Non-Performing Loan), the worse the bank's credit quality. [2]

Current loans provided by banks can turn into non-performing loans (substandard, doubtful, or imperfect) [3]. So that the possibility of banks experiencing financial distress is even greater. Current loans provided by banks can turn into non-performing loans (substandard, doubtful, or bad). To reduce the possibility of non-performing loans, it is necessary to have a systematic "self-introduction" system in the form of a list of events or symptoms that can cause credit problems.) Equation to calculate NPL shown below.

NPL $=\frac{\text { Troubeled credit }}{\text { Total Credit }} \times 100 \%$

\section{CAR (Capital Adequacy Ratio)}

Capital Adequacy Ratio is a ratio that shows how far all bank assets that contain risks (credits, investments, securities, claims on other banks) are also financed from the bank's capital funds in addition to obtaining funds from sources outside the bank, such as funds. From the community, loans and others [4]. Bank capital must be able to be used to maintain the possibility of risk of loss due to the movement of bank assets as a financial intermediary. In contrast, the movement of liabilities towards assets will cause various risks, and the increased role of bank assets as 
profit producers must be maintained. Working Capital is the company's investment in the form of cash, marketable securities, receivables and inventories, less current liabilities used to finance current assets. [5]

The CAR ratio is obtained from the comparison between owned capital and RiskWeighted Assets (RWA). Capital Adequacy Ratio is calculated by the formula below. [6]

$\mathrm{CAR}=\frac{\text { Bank } \text { Capital }}{A T M R}$

LDR (Loan to Deposit Ratio)
Liquidity is an indicator used by banks to measure the ability of banks to fulfill or pay their obligations (public deposits) that must be fulfilled immediately.

A bank is considered liquid if it has sufficient cash or other liquid assets, along with the ability to rapidly increase the number of funds from other sources, to enable it to meet payment obligations and other financial commitments on time [7]

Based on the circular letter, the calculation of LDR can be formulated as follows [8]:

LDR $=\frac{\text { Credit }}{\text { Third }- \text { party funds }} \times 100 \%$

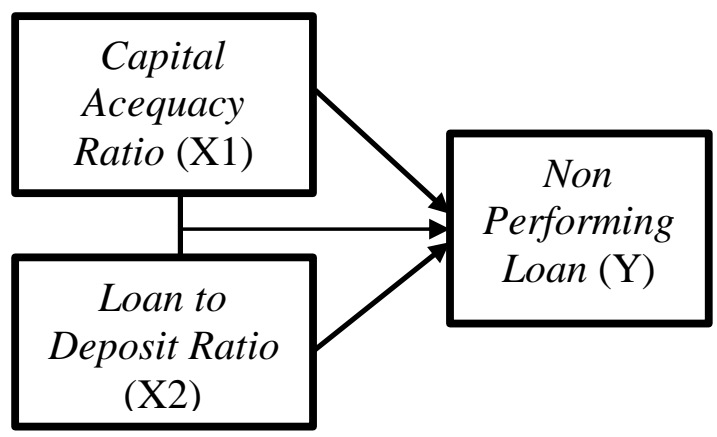

Figure 1 : Framework

\section{Hypothesis}

H1 : CAR impacts NPL partially

H2 : LDR impacts NPL partially

H3 : CAR and LDR impacts NPL simultaneously

\section{RESEARCH METHODOLOGY}

The type of method used in this research is quantitative research. The quantitative research method is called the positivistic method because it is based on the philosophy of positivism [9]. Researchers used data sources in the form of secondary data with data instruments in financial reports, annual reports from the Financial Services Authority (OJK) articles, books, and journals. The data used is a combination of cross-section data and time series.

The independent/independent variables in this study are CAR (X1) and $\operatorname{LDR}(\mathrm{X} 2)$. The dependent variable in this study is NPL (Y). The sample in this study was obtained through the purposive sampling method with 25 companies during the $2016-2020$ period. In this study, panel data analysis techniques were used with Eviews 9 software. The stages of 
testing carried out included determining the panel data estimation model, classical assumption test, partial test, simultaneous test and coefficient of determination test.

There are three types of estimation models in panel data, namely, CEM (common effect model), FEM (fixed-effect model) and REM (random effect model). In determining the model that is considered the best for the study, three tests were carried out, including the F Chow test, Hausman test, and the Lagrange Multiplier test. The Chow test was conducted to assess the most appropriate model from CEM (standard effect model) or FEM (fixedeffect model). The Hausman test is carried out in order to be able to choose the most appropriate model to use from FEM with REM. Finally, the Lagrange Multiplier test was conducted to determine the most appropriate model between CEM and REM.

\section{Classic Assumption Test}

A classical assumption test is carried out to assess whether the estimation model is feasible to be tested. Classical Assumption Tests include Normality Test, Multicollinearity Test, Heteroscedasticity Test and Autocorrelation Test. [10]. First, a normality test was conducted to test if the data in the study were usually distributed. Second, a multicollinearity test was conducted to test a close relationship between the independent variables (X1 and X2). Third, a heteroscedasticity test was conducted to determine the difference in variance from one observation residual to another observation. Finally, an autocorrelation test was conducted to determine the relationship between the residual observations. The autocorrelation test compared the statistical DW(Durbin-Watson) value and the DW(Durbin-Watson) value in the table.

\section{Partial Test and Simultaneous Test}

A partial test or $\mathrm{T}$ test is conducted to assess whether or not there is a relationship between each independent/independent variable on the dependent/bound variable. A simultaneous test or F test is conducted to see whether or not there is a relationship between independent variables simultaneously/simultaneously on the dependent variable.

\section{Coefficient of Determination}

The coefficient of determination is the value used to determine how strong the independent variable affects or represents the dependent variable. The value of the coefficient of determination is from 0 to 1 . The closer to 1 the independent variable is considered to represent the dependent variable, the better or, in other words, the level of influence of the independent variable on the dependent variable is greater. 


\section{RESULT AND DISCUSSION}

Table 2 : Estimation Model Determination Results

\begin{tabular}{lll}
\hline \multicolumn{1}{c}{ Test Type } & \multicolumn{1}{c}{ Result } & \multicolumn{1}{c}{ Conclusion } \\
\hline Chow Test & Prob. Cross section F $>\alpha \quad 04,12822>$ & $\begin{array}{l}\text { Common Effect Model (CEM) is the } \\
\text { most appropriate }\end{array}$ \\
Hausman Test & Not done, because the chow test showed & $\begin{array}{l}\text { Lagrange multiplier test is carried out } \\
\text { immediately }\end{array}$ \\
CEM as the most appropriate model & Random Effect Model (REM) is the \\
Mugrange & Prob. Breush-Pangan $>\alpha 0,000>0,05$ & most appropriate \\
\hline
\end{tabular}

Source: Prosessed data (2020)

Based on the conclusion from the results of data processing in table 1 , it can be determined that the model from the best estimate to be applied is REM (Random Effect Model).

\section{Classic Assumption Test}

Table 3 : Exemplary Suspicion Test Results

\begin{tabular}{ccc}
\hline Test Type & Result & Conclusion \\
\hline Normality test & Prob.Jarque Berra $>\alpha \quad 0,094289>0,05$ & Data is normally distributed \\
Multicollinearity Test & Highest correlation $0.07<0.090$ & $\begin{array}{c}\text { There is no multicollinearity } \\
\text { between independent variables }\end{array}$ \\
Heteroscedasticity Test & Obs ${ }^{*} R$-Squared is $0.1156>0.05$ & There is no heteroscedasticity \\
Autocorrelation Test & du 1.5495. DW $1.991397>(\mathrm{du}) 1.5495$ & There is no autocorrelation
\end{tabular}

Source: Prosessed data (2020)

From the classical assumption test results shown in Table 3, it can be concluded that the research data has met the requirements of the classical assumption so that the data is considered worthy of research.

\section{Hypothesis Testing \\ Partial Test}

Table 4 : Partial Test

\begin{tabular}{crrrc}
\hline Variable & Coefficient & Std. Error & t-Statistic & Prob. \\
\hline C & 6.328344 & 1.078981 & 5.865115 & 0.0000 \\
X1 & -0.106493 & 0.030362 & -3.507426 & 0.0006 \\
X2 & -0.011944 & 0.010700 & -1.116183 & 0.2665
\end{tabular}


The first partial hypothesis test: the calculated $t$ value of the independent variable CAR is 3.507 smaller than $\mathrm{t}$ table 2.068 , and the significance level is 0.0006 smaller than 0.05 . The independent variable is said to have a significant effect on the dependent variable.
The second partial hypothesis test: the $t$ value of the independent variable LDR is -1.16183 smaller than $\mathrm{t}$ table 2.068 , and the significance level is 0.2665 greater than 0.05 . The independent variable is said to have no significant effect on the dependent variable.

\section{Simultaneous Test}

Table 5 : Simultaneous Test

\begin{tabular}{|c|c|c|c|}
\hline \multicolumn{3}{|c|}{ Weighted Statistics } & \multirow[b]{2}{*}{1.546594} \\
\hline$\overline{\mathrm{R} \text {-squared }}$ & 0.101534 & Mean ward var & \\
\hline Changed R-squared & 0.086805 & S.D. subordinate var & 1.043628 \\
\hline S.E. of regression & 0.997304 & Total squared resid & 121.3431 \\
\hline F-statistic & 6.893501 & Durbin-Watson stat & 1.328513 \\
\hline Prob(F-statistic) & 0.001457 & & \\
\hline
\end{tabular}

Source: Processed Data by Eviews 9

This test determines $\mathrm{H} 1$ whether there is a simultaneous effect on CAR and LDR) on NPL.

In the results of table 4.11, the calculated F value is $6.89>3.42$ from the f-table with a significant value of 0.001457 , which is lower than 0.05. This means that CAR and LDR simultaneously have a significant effect on NPL.
Hypothesis 1 (H1), which states that the Capital Adequacy Ratio and Loan to Deposit Ratio have a significant simultaneous effect on Non-Performing Loans, is accepted. This is in line with the results of previous research, which showed that the Capital Adequacy Ratio (CAR) and Loan to Deposit Ratio (LDR) values ) have a significant positive effect on Non Performing Loans (NPL). [11]

\section{Coefficient of Determination}

Table 6 : Determination Test

\begin{tabular}{lcll}
\hline \multicolumn{3}{c}{ Weighted Statistics } & \\
\hline R-squared & 0.101534 & Mean ward var & 1.546594 \\
Adjusted R-squared & 0.086805 & S.D. subordinate var & 1.043628 \\
S.E. of regression & 0.997304 & Total squared resid & 121.3431 \\
F-statistic & 6.893501 & Durbin-Watson stat & 1.328513 \\
Prob(F-statistic) & 0.001457 & & \\
\hline
\end{tabular}

Source: Processed Data by Eviews 9 
Table 6 shows the R-squared value of 0.101534 . This figure will be converted into a percent structure, which implies the level of commitment of the impact of the independent factor on the dependent variable. It means that the influence of the Capital Adequacy Ratio (CAR) and Loan to Deposit Ratio (LDR) variables in this study explains $10.15 \%$ of the Non-Performing Loan variable (NPL). At the same time, the remaining $89.85 \%$ is affected by different factors that are not estimated in this relapse model.

Effect of Capital Adequacy Ratio (X1) on Non-Performing Loans (Y). in table 4.12, the CAR probability value of 0.0006 is smaller than 0.05 with a t-statistic value of $t$ count $3.507<2.068 \mathrm{t}$ table. This means that CAR (X1) affects NPL (Y). the effect of Loan to Deposit Ratio (X2) on Non-Performing Loans (Y). In Table 4, the probability value of LDR is 0.2665 , which is greater than 0.05 with a tcount value of $-1.116<2.068 \mathrm{t}$ table. This means that LDR (X2) does not affect NPL (Y).

\section{CONCLUSION}

For banking, traditional business banks in Indonesia are natural for Indonesia Money Service to focus more on Vehicle and LDR factors. For example, where the capital adequacy claimed by the organization is critical to the resilience of the business in case of identified problems with the organization's accounts.

For banking management, it is better to consider the Loan to Deposit Ratio (LDR) factor in determining the normal level of benefits by considering the level of effectiveness and the nature of the loan.

Banks must be more thorough in the feasibility analysis stage of prospective debtors so that the loans disbursed are right on target and effective. In addition, even after disbursing credit, the analysis must ensure that the credit provided is used according to its designation, given the current high level of credit abuse. This is necessary to suppress the NPL.

For further researchers, it is recommended to use other external factors that influence NPLs, which are more changing and more shifting, to obtain relevant and better results, such as Profit from Resources (ROA), Return on Value (ROE), External Assets (TPF) to factor in. Then, at that time, File Composite Stock Value (JCI), Gross Homegrown Item (Gross Domestic Product), Swapping Scale, Credit Volume for external elements. It can be seen the unique and up-to-date conditions

\section{REFERENCE}

[1] Bonita, "Pengaruh Non Performing Loan dan Loan Deposit Ratio Terhadap Return On Assets Pada PT. Bank Mandiri (Persero) Tbk. dan Entitas Anak," Jurnal finacc, p. 10, 2017. [in bahasa]

[2] Surat Edaran Bank Indonesia No.6/23/DPNP tanggal 31 Mei 2004 [in bahasa]

[3] Kasmir, Bank Dan Lembaga Keuangan Lainnya (cetakan ketujuh belas)., 
Jakarta: PT Raja Grafindo Parsada, 2016. [in bahasa]

[4] D.riana, L.diyani. 2016. "Pengaruh rasio keuangan dalam memprediksi perubahan laba pada industri farmasi (Studi kasus BEI tahun 2011-2014)." jurnal online insan akutan 16-42. [in bahasa]

[5] Sujarweni, analisis laporan keuangan untuk bisnis teori dan kasus, Yogyakarta: pustaka baru press, 2017. [in bahasa]

[6] SE BI No.13/24/DPNP/2011 rasio Capital Adequacy Ratio [in bahasa]

[7] Darwani, Manajemen Perbankan, Jakarta: Bumi Aksara, 2016. [in bahasa]
[8] SE BI No.13/30/DPNP tanggal 16 Desember 2011 [in bahasa]

[9] Sugiyono, Metode penelitian kuantitatif, kualitatif fan R\&D, Bandung: Alfabeta, 2017. [in bahasa]

[10] Ghozali, Aplikasi Analisis Multivarian dengan Program IBM SPSS 23. Edisi Kedelapan, Semarang: Badan Penerbit Universitas Diponegoro, 2016. [in bahasa]

[11] Andreani Caroline Barus, "Effect Of LDR,NPL and BOPO on Profitabilities Based on CAR," Journal of Management, p. 4(4), 2018. 